\title{
Hydrochemical Characterization of Water Resources From Reverse Osmosis Desalination Plants
}

\author{
Francisco Pio de Souza Antas ${ }^{1}$, Nildo da Silva Dias ${ }^{2}$, André Moreira de Oliveira ${ }^{3}$, \\ Osvaldo Nogueira de Sousa Neto ${ }^{4}$, Cleyton dos Santos Fernandes ${ }^{2}$, Neyton de Oliveira Miranda ${ }^{2}$, \\ Gabriela Cemirames de Sousa Gurgel ${ }^{2}$, Francisco Souto de Sousa Junior ${ }^{4}$, Alexandre de Oliveira Lima ${ }^{5}$ \\ \& Miguel Ferreira Neto ${ }^{2}$ \\ ${ }^{1}$ Federal Institute of Rio Grande do Norte State, Caicó, RN, Brazil \\ ${ }^{2}$ Center of Agrarian Sciences, Federal Rural University of the Semi-Arid, Mossoró, RN, Brazil \\ ${ }^{3}$ Department of Science and Technology, Federal Rural University of the Semi-Arid, Caraúbas, RN, Brazil \\ ${ }^{4}$ Department of Exact, Technological and Human Sciences, Federal Rural University of the Semi-Arid, Angicos, \\ $\mathrm{RN}$, Brazil \\ ${ }^{5}$ State University of Rio Grande do Norte, Mossoró, RN, Brazil \\ Correspondence: Cleyton dos Santos Fernandes, Center of Agrarian Sciences, Federal Rural University of the \\ Semi-Arid, Mossoró, RN, Brazil. Tel: 55-088-996-322-948. E-mail: cleyton1959@hotmail.com
}

$\begin{array}{lr}\text { Received: July 12, 2018 } & \text { Accepted: September 1, } 2018 \quad \text { Online Published: November 15, } 2018 \\ \text { doi:10.5539/jas.v10n12p445 } & \text { URL: https://doi.org/10.5539/jas.v10n12p445 }\end{array}$

\begin{abstract}
The desalination of the brackish waters is a technology of coexistence with the semi-arid and its adoption implies in determining the environmental impacts due to the reject brine generated. Therefore, this work evaluated the hydrochemical characteristics of well water (feed water), drinking water (purified) and reject brine from reverse osmosis desalination plants in Western Meso-region, Rio Grande do Norte state, Brazil. During the periods between October 2013 and November 2014, four water samples were taken at seven inland desalination plants in communities and rural settlements. The hydrochemical characteristics of the waters were evaluated using multivariate statistical analysis. The following physico-chemical parameters of water collected were evaluated: electrical conductivity $\left(\mathrm{EC}_{\mathrm{w}}\right), \mathrm{pH}$, concentrations of cations (sodium, potassium, calcium and magnesium) and anions (chloride, carbonate and bicarbonate), Sodium Adsorption Ratio, Langelier Saturation Index, Stability Index of Ryznar, and the Calcium/Magnesium ratio. Well water and reject brine were classified into six groups, while purified water was classified into seven groups with different levels of risk of salinization, sodification and ions toxicity.
\end{abstract}

Keywords: water quality, salinization, environmental impacts

\section{Introduction}

A major challenge for the Brazilian semi-arid region is to promote the supply of water to families living in rural areas and also to provide these communities with productive capacity. Thus, water issues in semi-arid zone are crucial in overcoming obstacles to development (Cirilo, 2008), because, due to the irregular rainfall regime, surface resources are often scarce or of poor quality and the storage of water in surface reservoirs is difficult, especially during long periods of low rainfall.

In the specific case of regions afflicted by water scarcity, such as the semi-arid of northeastern Brazil, food production should be based on principles and techniques of coexistence with drought, as well as on the use of alternative sources and rational use of water resources available.

In this context, several drought coexistence techniques have been used to improve access and increase water availability to meet the diffused rural demand in arid and semi-arid regions. As examples, we present the underground dams (Lima et al., 2017), as well as groundwater available after public investments in well drilling (Soares et al., 2006). 
Although groundwater can be used for consumption and also for agricultural production, guaranteeing the food and nutritional security of rural families, these water sources present in most cases restrictions of use for human consumption due to high-salinity problems (Oliveira et al., 2017).

The Brazilian Federal Government's 'Água Boa' Program seeks to solve this problem by installing reverse osmosis water treatment plants in several rural communities in the Northeast Region, in order to obtain drinking water for families through desalination of water from wells with high-salinity. This technology tends to alleviate the precarious conditions of water supply in the northeastern localities contemplated by governmental programs. Thus, the problem of salinization does not mean that these waters cannot be exploited, because where reverse osmosis desalination technology has been used in Northeast Brazil, the exploitation of these sources becomes viable (Soares et al., 2006).

A restriction of the desalination process is the production of an amount of reject brine ranging from 40 to $70 \%$ of the total feed water used, depending on the percent recovery of desalination plant and the quality water of feed (Bush et al., 2017). As water is the main input of irrigation, both its quantity and quality are very relevant to the success of its application, without causing damage to the soil-plant system and irrigation equipment (Mantovani et al., 2007).

The use of saline water in irrigation may present a risk to both crop development and production, as salinity effects may lead to a reduction of up to $50 \%$ in productivity of some species (Barroso et al., 2011).

Considering the above, greater attention to the rational use of water resources in the semiarid region, mainly in what concerns the efficiency of the treatment of brackish waters by reverse osmosis, besides the monitoring and management of groundwater brackish wells and/or reject brine, by means of the evaluation of its quality. In this context, this study was carried out to determine the hydrochemistry of the water from the desalination process in seven reverse osmosis desalination plants located in rural communities and settlements in the State of Rio Grande do Norte, in order to use rationally and manage sustainably the water resources.

\section{Method}

The research was carried out between 2013 and 2014 in communities and rural settlements of the West Region of the state of Rio Grande do Norte (West Potiguar), Brazil, which have units of water catchment and treatment for desalination.

The West Potiguar mesoregion presents characteristic landscape and climate, possessing as dominant vegetation the hyperxerophilic 'caatinga'. According to the classification of Köppen, the predominant climate of the region is the BSw'h' type, hot and semi-arid, with a rainy season of approximately four months predominating between February and May, with March and April months having the higher average annual precipitation of about 550-750 $\mathrm{mm}$ and 27 to $29^{\circ} \mathrm{C}$ average temperature.

The locations where the brackish water treatment plants were installed were identified through consultation with the cadastral survey of the Rio Grande do Norte State Water Resources Secretariat (SEMARH).

Community leaders were interviewed for technical descriptions of the wells. This information was used to identify wells with characteristics favorable to monitoring, such as similarity between them, proper maintenance, and daily use of the desalinator. In this way, seven treatment plants were selected in three settlement projects (Boa Fé and Alagoinha in the municipality of Mossoró, and Lagoa Rasa in Apodi) and four rural communities (Juazeiro, in the municipality of Apodi, Alagoinhas in Pau dos Ferros, Jacu in Francisco Dantas, and Ema, in the municipality of José da Penha).

Sampling of water from the desalination process at each site (brackish water-feed, purified-drinking water and reject brine) were performed every three months, in order to verify the hydrochemical changes in all seasons. The collection periods were: $\mathrm{E}_{1}=$ October/November $(2013)$ - Dry period, practically no rainfall; $\mathrm{E}_{2}=$ February/March (2014), beginning of the rainy season; $E_{3}=$ June/July (2014), end of the rainy season, and $E_{4}=$ October/November (2014), closing the cycle of twelve months, again in the dry season.

The samples were collected and stored in $500 \mathrm{~mL}$ opaque polypropylene bottles, hermetically sealed. They were refrigerated and taken for analysis to the Laboratory of Water, Soil and Plant Analysis (LASAP) of the Federal Rural Semiarid University (UFERSA).

The determinations carried out were of Electrical Conductivity ( $E C$ in $\left.\mathrm{dS} \mathrm{m}^{-1}\right)$, hydrogen ion potential $(\mathrm{pH})$, the concentrations of Sodium $\left(\mathrm{Na}^{+}\right)$, Calcium $\left(\mathrm{Ca}^{2+}\right)$, Magnesium $\left(\mathrm{Mg}^{2+}\right)$, Potassium $\left(\mathrm{K}^{+}\right)$, Chloride $\left(\mathrm{Cl}^{-}\right)$Carbonate $\left(\mathrm{CO}_{3}{ }^{2-}\right)$, and Bicarbonate $\left(\mathrm{HCO}_{3}{ }^{-}\right)$, according to the methodologies proposed by Richards (1954). The sodium absorption ratio (SAR) was also calculated for the classification of the samples as to the risk of sodification and 
problems of infiltration in the soil caused by the sodicity of the water. The criteria proposed by Ayers \& Westcott (1999) were used in the analysis of water quality for irrigation purposes (Table 1).

Table 1. Classes of restriction of use for irrigation of water from saline wells in rural areas of the West Potiguar

\begin{tabular}{|c|c|c|c|c|c|}
\hline \multirow{2}{*}{ Potencial problem } & \multirow{2}{*}{ Irrigation Systems } & \multirow{2}{*}{ Variables } & \multicolumn{3}{|c|}{ Classes of restriction } \\
\hline & & & None & Slight to Moderate & Severe \\
\hline \multirow[t]{2}{*}{ Salinization } & & $\mathrm{EC}_{\mathrm{w}}\left(\mathrm{dS} \mathrm{m}^{-1}\right)$ & $<0.7$ & $0.7-3.0$ & $>3.0$ \\
\hline & & DTS $\left(\mathrm{mg} \mathrm{L}^{-1}\right)$ & $<450$ & $450-2000$ & $>2000$ \\
\hline Sodification & & SAR $\left(\mathrm{mmol} \mathrm{L}^{-1}\right)^{1 / 2}$ & \multicolumn{3}{|c|}{$\mathrm{EC}_{\mathrm{w}}\left(\mathrm{dS} \mathrm{m}^{-1}\right)$} \\
\hline \multirow[t]{5}{*}{ (reduction in soil water infiltration) } & & 0 to 3 & $>0.7$ & $0.7-0.2$ & $<0.2$ \\
\hline & & 3 to 6 & $>1.2$ & $1.2-0.3$ & $<0.3$ \\
\hline & & 6 to 12 & $>1.9$ & $1.9-0.5$ & $<0.5$ \\
\hline & & 12 to 20 & $>2.9$ & 2.9-1.3 & $<1.3$ \\
\hline & & 20 to 40 & $>5.0$ & $5.0-2.9$ & $<2.9$ \\
\hline \multirow[t]{5}{*}{ Toxicity of specific ions to the crops } & Surface & $\operatorname{RAS}\left(\mathrm{mmol}_{\mathrm{c}} \mathrm{L}^{-1}\right)^{1 / 2}$ & $<3.0$ & $3.0-9.0$ & $>9.0$ \\
\hline & Sprinkler & $\mathrm{Na}^{+}\left(\mathrm{mmol}_{\mathrm{c}} \mathrm{L}^{-1}\right)$ & $<3.0$ & $>3.0$ & \\
\hline & Surface & $\mathrm{Cl}^{-}\left(\mathrm{mmol}_{\mathrm{c}} \mathrm{L}^{-1}\right)$ & $<4.0$ & $4.0-10.0$ & $>10.0$ \\
\hline & Sprinkler & $\mathrm{Cl}^{-}\left(\mathrm{mmol}_{\mathrm{c}} \mathrm{L}^{-1}\right)$ & $<3.0$ & $>3.0$ & \\
\hline & Sprinkler & $\mathrm{HCO}_{3}^{-}\left(\mathrm{mmol}_{\mathrm{c}} \mathrm{L}^{-1}\right)$ & $<1.5$ & $1.5-8.5$ & $>8.5$ \\
\hline \multirow[t]{3}{*}{ Clogging in drip irrigation systems } & & $\mathrm{pH}$ & $<7.0$ & $7.0-8.0$ & $>8.0$ \\
\hline & & Fe total $\left(\mathrm{mg} \mathrm{L}^{-1}\right)$ & $<0.1$ & $0.1-1.5$ & $>1.5$ \\
\hline & & LSI & $<0.0$ & $>0.0$ & \\
\hline
\end{tabular}

Note $. \mathrm{EC}_{\mathrm{w}}=$ electrical conductivity of water, $\mathrm{TDS}=$ Total dissolved solids; $\mathrm{SAR}=$ sodium absorption ratio; $\mathrm{LSI}$ $=$ Langelier saturation index.

The results were interpreted through the multivariate statistics of hierarchical grouping using the least variance method, also known as Ward's method (Ward, 2012). The variables used for the cluster analysis were the electric conductivity (EC), the concentrations of sodium, potassium, calcium, magnesium, carbonates, bicarbonates and chloride, as well as the Langelier Saturation Index (LSI) and Stability Index of Ryznar (SIR).

The Ward's method is a hierarchical model that uses a Euclidean distance to measure the similarity or dissimilarity between individuals that is the distance between individuals $\mathrm{Xi}$ and $\mathrm{Xj}$, according to Equation 1 .

$$
\mathrm{d}_{\mathrm{ij}}=\left[\mathrm{X}_{\mathrm{i}}-\mathrm{X}_{\mathrm{j}}\right]=\left[\sum_{\mathrm{k}=1}^{\mathrm{P}}\left(\mathrm{X}_{\mathrm{i}, \mathrm{k}}-\mathrm{X}_{\mathrm{j}, \mathrm{k}}\right)^{2}\right]^{1 / 2}
$$

Ward's method proposes that at any stage of the analysis the loss of information resulting from the grouping of elements between groups is measured by the Sum of Squares of Deviations (SSD) of each point to the mean of the group to which it belongs, according to Equation 2:

$$
\mathrm{SQD}=\sum_{\mathrm{i}=1}^{\mathrm{n}} \mathrm{x}_{\mathrm{i}}^{2}-\frac{1}{\mathrm{n}}\left(\sum_{\mathrm{x}=1}^{\mathrm{n}} \mathrm{x}_{\mathrm{i}}\right)^{2}
$$

where, $\mathrm{n}=$ total number of elements of the cluster; $\mathrm{xi}=\mathrm{i}$-th element of the cluster.

In this method, the groups are formed by maximizing the homogeneity within them and the heterogeneity between the groups. The sum of squares within the groups is used as a measure of homogeneity. That is, Ward's method attempts to minimize the sum of squares within the group. The groups formed in each step are the solution group with the smallest sum of squares (Sharma, 1996).

For calculations of the Langelier and Ryznar indexes, which determine the fouling or corrosive trends, the $35{ }^{\circ} \mathrm{C}$ temperature was taken as the basis, because it was for the average maximum temperature at sample times. According to American Public Health Association [APHA] (2005), the alkalinity was taken as the $\mathrm{HCO}_{3}{ }^{-}$ concentration because the $\mathrm{pH}$ of the samples of the three types of water was in the range of 4.4 to 8.4.

The calculation of the Langelier Saturation Index was performed according to Equations 3 to 8 , and the interpretation of the results is presented in Table 2 .

$$
\mathrm{ISL}=\mathrm{pH}-\mathrm{pH}_{\mathrm{e}}
$$




$$
\begin{gathered}
\mathrm{pH}_{\mathrm{e}}=9.3+\mathrm{A}+\mathrm{B}-(\mathrm{C}+\mathrm{D}) \\
\mathrm{A}=\frac{\log (\mathrm{TDS})-1}{10} \\
\mathrm{~B}=[13.12-\log (\mathrm{T}+273)]+34.55 \\
\mathrm{C}=\left[\log \left(\mathrm{Ca}^{2+}\right)\right]-0.34 \\
\mathrm{D}=\log (\mathrm{Alc})
\end{gathered}
$$

Where, TDS $=$ Total Dissolved Solids in $\mathrm{mg} \mathrm{L}^{-1} ; \mathrm{T}=$ Temperature in ${ }^{\circ} \mathrm{C} ; \mathrm{Ca}^{2+}=$ concentration of calcium in $\mathrm{mg}$ $\mathrm{L}^{-1} ;$ Alk1 = Alkalinity in $\mathrm{CaCO}_{3}$.

Table 2. Risks of incrustation or corrosion of waters of saline wells of the rural localities of the West Potiguar, according to the Langelier Saturation Index (LSI)

\begin{tabular}{ll}
\hline LSI value & Indication \\
\hline$>4$ & Severe Incrustation \\
3 to 4 & Moderate Incrustation \\
1 to 3 & Mild Incrustation \\
0.5 to 1 & Very Mild Incrustation \\
-0.5 to 0.5 & Balanced \\
-2 to -0.5 & Mild Corrosion \\
-5 to -2 & Moderate Corrosion \\
$<-5$ & Severe Corrosion \\
\hline
\end{tabular}

Source: Adapted from Grades (2004).

The Ryznar Stability Index was determined according to Equation 9, with interpretation of the results as presented in Table 3.

$$
\mathrm{IER}=2 \mathrm{pH}_{\mathrm{e}}-\mathrm{pH}
$$

Where, $\mathrm{pH}_{\mathrm{e}}: \mathrm{pH}$ of $\mathrm{CaCo}_{3}$ saturation.

Table 3. Risks of incrustation or corrosion of waters of saline wells of the rural localities of the West Potiguar according to the Ryznar Stability Index (RSI)

\begin{tabular}{ll}
\hline RSI value & Indication \\
\hline$<4$ & Severe Incrustation \\
4 to 5 & Strong Incrustation \\
5 to 6 & Mild Incrustation \\
6 to 7 & Balanced \\
7 to 7.5 & Moderate Corrosion \\
7.5 to 9 & Strong Corrosion \\
$>9.0$ & Severe Corrosion \\
\hline
\end{tabular}

Source: adapted from Grades (2004).

\section{Results and Discussion}

\subsection{Brackish Water From Wells}

The analysis of the dendrogram indicated six groups with $39.28 \%$ (Group 1), $14.28 \%$ (Group 2) and 25.00\% of the samples (Group 3) and three groups $(4,5$, and 6$)$ with $7.14 \%$ of the samples each (Figure 1). 


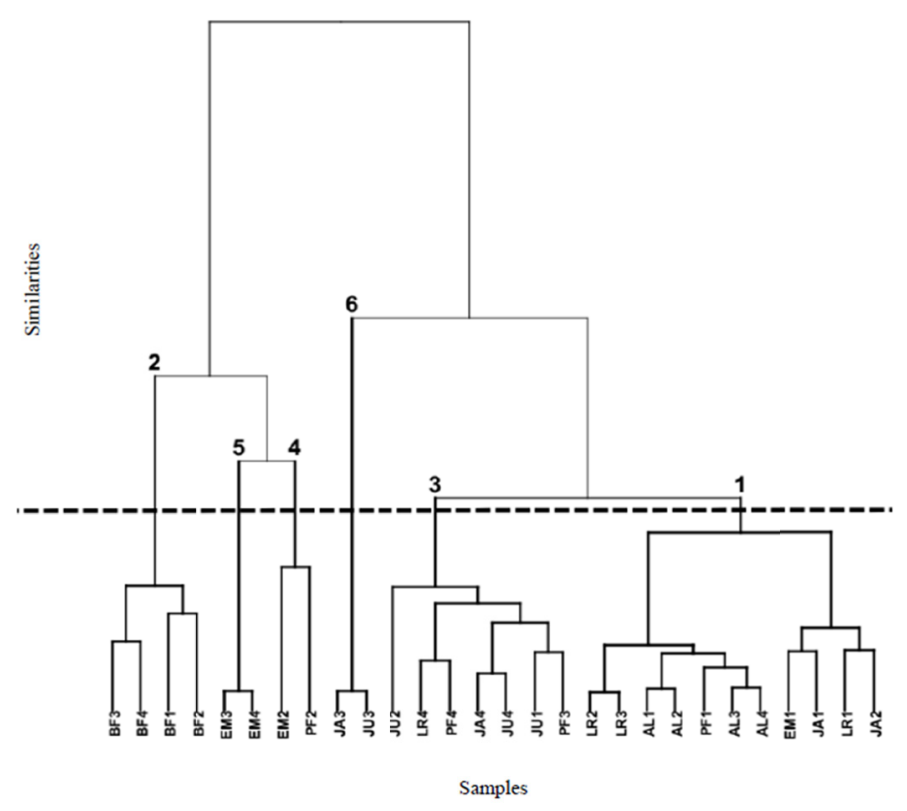

Figure 1. Dendrogram of the hierarchical clustering analysis for the 28 points of well saltwater collection at the desalinations plants in West Potiguar

It is inferred from the dendogram that Group 6, composed by the communities of Jacu and Juazeiro analyzed in the rainy season, despite the great similarity between its components, presented the highest coefficient of Euclidean distance in relation to the other groups. This group had very low $\operatorname{EC}_{\mathrm{w}}\left(0.17\right.$ and $\left.0.3 \mathrm{dS} \mathrm{m}^{-1}\right)$, as well as LSI values (-1.33 and -1.09) and RSI values (9.67 and 9.17) presenting moderate risks of corrosion (Table 4). 
Table 4. Results of the hierarchical clustering analysis by the Ward's method for the 28 points of water collection from saline wells in the rural settlements of the West Potiguar

\begin{tabular}{|c|c|c|c|c|c|c|c|c|c|c|c|c|}
\hline Group & Locality & $\mathrm{EC}_{\mathrm{w}}$ & $\mathrm{K}^{+}$ & $\mathrm{Na}^{+}$ & $\mathrm{Ca}^{2+}$ & $\mathrm{Mg}^{2+}$ & $\mathrm{Cl}^{-}$ & $\mathrm{CO}_{3}{ }^{2-}$ & $\mathrm{HCO}_{3}^{-}$ & SAR & LSI & RSI \\
\hline & & $\mathrm{dS} \mathrm{m}^{-1}$ & -----. & -------- & -------- & $\mathrm{mmol}_{\mathrm{c}}$ & -1 & -------- & -------. & & & \\
\hline \multirow[t]{11}{*}{ G1 } & $\mathrm{LR}_{2}$ & 1.10 & 0.39 & 7.30 & 3.70 & 2.30 & 4.20 & 0.60 & 7.70 & 4.20 & 0.89 & 5.69 \\
\hline & $\mathrm{LR}_{3}$ & 0.58 & 0.26 & 5.05 & 3.10 & 1.60 & 3.80 & 0.50 & 7.60 & 3.30 & 0.74 & 5.91 \\
\hline & $\mathrm{AL}_{1}$ & 1.09 & 0.19 & 2.67 & 6.00 & 1.80 & 6.20 & 0.40 & 5.00 & 1.40 & 1.16 & 5.39 \\
\hline & $\mathrm{AL}_{2}$ & 1.25 & 0.24 & 2.76 & 7.30 & 2.70 & 7.20 & 0.40 & 6.50 & 1.20 & 1.37 & 5.00 \\
\hline & $\mathrm{AL}_{3}$ & 1.09 & 0.21 & 5.66 & 6.00 & 1.80 & 6.20 & 0.40 & 5.00 & 2.90 & 0.84 & 5.71 \\
\hline & $\mathrm{AL}_{4}$ & 1.03 & 0.21 & 5.70 & 5.90 & 1.70 & 6.10 & 0.10 & 5.00 & 2.90 & 0.54 & 6.06 \\
\hline & $\mathrm{PF}_{1}$ & 2.10 & 0.24 & 7.44 & 10.30 & 5.30 & 10.60 & 0.40 & 3.20 & 2.70 & 0.87 & 5.64 \\
\hline & $\mathrm{EM}_{1}$ & 2.16 & 0.19 & 11.29 & 5.40 & 3.50 & 15.20 & 1.80 & 7.30 & 5.40 & 1.13 & 5.23 \\
\hline & $\mathrm{JA}_{1}$ & 2.54 & 0.29 & 8.49 & 12.55 & 1.45 & 23.20 & 1.00 & 3.70 & 3.20 & 1.25 & 5.03 \\
\hline & $\mathrm{LR}_{1}$ & 0.99 & 0.01 & 6.83 & 3.50 & 1.45 & 3.40 & 1.40 & 4.20 & 4.30 & 0.47 & 6.23 \\
\hline & $\mathrm{JA}_{2}$ & 2.60 & 0.32 & 8.38 & 13.00 & 1.30 & 23.60 & 2.00 & 3.80 & 3.10 & 0.00 & 6.13 \\
\hline \multirow[t]{4}{*}{ G2 } & $\mathrm{BF}_{3}$ & 6.20 & 0.69 & 33.18 & 29.10 & 17.20 & 71.40 & 0.00 & 3.40 & 6.90 & 1.11 & 5.07 \\
\hline & $\mathrm{BF}_{4}$ & 5.72 & 0.81 & 55.01 & 36.50 & 24.50 & 66.00 & 0.00 & 4.30 & 9.96 & 1.18 & 4.80 \\
\hline & $\mathrm{BF}_{1}$ & 6.20 & 0.11 & 25.82 & 29.49 & 8.71 & 64.40 & 1.40 & 2.20 & 5.90 & 1.26 & 4.75 \\
\hline & $\mathrm{BF}_{2}$ & 6.40 & 2.03 & 26.89 & 33.00 & 9.00 & 64.00 & 0.40 & 5.00 & 5.90 & 1.25 & 4.65 \\
\hline \multirow[t]{7}{*}{ G3 } & $\mathrm{JA}_{4}$ & 2.30 & 0.70 & 20.49 & 15.00 & 6.50 & 22.00 & 0.00 & 3.70 & 6.25 & 0.72 & 5.67 \\
\hline & $\mathrm{JU}_{4}$ & 1.95 & 0.93 & 11.46 & 14.00 & 8.50 & 30.00 & 0.00 & 2.80 & 3.42 & 0.55 & 5.98 \\
\hline & $\mathrm{JU}_{1}$ & 2.01 & 0.40 & 4.99 & 10.02 & 4.98 & 19.40 & 0.00 & 1.50 & 1.80 & 0.26 & 6.68 \\
\hline & $\mathrm{PF}_{3}$ & 0.57 & 0.37 & 10.13 & 2.20 & 3.30 & 4.00 & 0.40 & 0.30 & 6.11 & 0.51 & 7.18 \\
\hline & $\mathrm{LR}_{4}$ & 0.95 & 0.09 & 13.42 & 3.20 & 1.10 & 4.40 & 0.10 & 7.60 & 9.15 & 0.81 & 5.89 \\
\hline & $\mathrm{PF}_{4}$ & 0.98 & 0.59 & 15.72 & 2.40 & 4.30 & 4.60 & 0.40 & 4.60 & 8.59 & 0.42 & 6.63 \\
\hline & $\mathrm{JU}_{2}$ & 2.30 & 2.49 & 6.28 & 13.10 & 2.90 & 20.60 & 0.00 & 2.30 & 2.20 & 0.26 & 6.39 \\
\hline \multirow[t]{2}{*}{$\mathrm{G} 4$} & $\mathrm{EM}_{2}$ & 2.60 & 2.49 & 15.14 & 5.90 & 4.40 & 13.20 & 1.20 & 13.00 & 6.70 & 1.21 & 4.96 \\
\hline & $\mathrm{PF}_{2}$ & 7.22 & 2.28 & 7.56 & 40.80 & 21.60 & 14.20 & 0.80 & 8.00 & 1.40 & 1.71 & 3.82 \\
\hline \multirow[t]{2}{*}{$\mathrm{G} 5$} & $\mathrm{EM}_{3}$ & 1.93 & 0.61 & 37.79 & 4.20 & 5.80 & 12.20 & 0.00 & 8.90 & 16.90 & 0.75 & 5.80 \\
\hline & $\mathrm{EM}_{4}$ & 1.98 & 0.67 & 35.72 & 4.60 & 5.70 & 12.80 & 0.10 & 9.30 & 15.74 & 1.02 & 5.46 \\
\hline \multirow[t]{2}{*}{ G6 } & $\mathrm{JA}_{3}$ & 0.17 & 0.30 & 0.71 & 1.20 & 1.30 & 2.40 & 0.00 & 0.40 & 0.64 & -1.33 & 9.67 \\
\hline & $\mathrm{JU}_{3}$ & 0.30 & 0.24 & 1.97 & 1.80 & 1.50 & 3.00 & 0.00 & 0.50 & 1.54 & -1.09 & 9.17 \\
\hline
\end{tabular}

Note. $\mathrm{EC}=$ electrical conductivity; $\mathrm{SAR}=$ sodium absorption ratio; $\mathrm{LSI}=$ Langelier saturation index; RSI $=$ Ryznar stability index. The initials of the localities $(\mathrm{JA}=\mathrm{Jacu}, \mathrm{LR}=$ Lagoa Rasa, $\mathrm{EM}=\mathrm{Ema}, \mathrm{AL}=$ Alagoinha, $\mathrm{JU}=\mathrm{Juazeiro}, \mathrm{BF}=$ Boa Fé, $\mathrm{PF}=$ Pau dos Ferros) are accompanied by the numbers 1, 2, 3, and 4, corresponding respectively to collection periods: E1; E2; E3, and E4.

Another fact to be denoted is that the community of Boa Fé (Group 2), independently of the sampling period, shows a high dissimilarity to the others as a function of their ionic concentrations (Figure 2).

The group 1 was composed from the smallest sum of squares of $\mathrm{EC}_{\mathrm{w}}$ and electrical conductivity values recorded were between $0.58 \mathrm{dS} \mathrm{m}^{-1}$ and $2.60 \mathrm{dS} \mathrm{m}^{-1}$ (Table 4). According to Ayers and Westcott (1999), except for the locality of Lagoa Rasa at the end of the rainy season - LR3 $\left(\mathrm{EC}_{\mathrm{w}}=0.58 \mathrm{dS} \mathrm{m}^{-1}\right)$, all water samples collected in the wells present a moderate risk of salinization, being necessary the adoption of irrigation management practices to avoid the accumulation of salts in the root zone, as for example the application of a leaching fraction. In relation to the risk of infiltration problems, samples AL1, AL2, AL3, AL4, PF1, EM1, JA1, LR1 and JA2 presented no restriction, while LR1, LR2 and LR3 presented moderate restriction. In this group, only LR1 and JA2 showed no corrosive or fouling tendency, while the other samples showed a slight propensity to form incrustations, which can cause obstruction in emitters in the localized irrigation.

It is also observed that only AL1 and AL2 showed no restriction due to $\mathrm{Na}^{+}$toxicity, which may cause calcium deficiency to the culture, but all the samples listed in this group showed restriction due to $\mathrm{Cl}^{-}$toxicity (Ayers \& Westcott, 1999). 
According to Antas and Morais (2011), if the chloride is not adsorbed, it easily moves through the liquid fraction of the soil being absorbed by the roots and translocated by the transpiration to the leaves, where it accumulates and can produce damages. Its characteristic symptoms are necrosis and burns on the leaves. In fruit trees, symptoms of intoxication may appear from a $0.3 \%$ concentration of chloride.

Group 2 was formed by the smallest sum of squares of LSI and was composed of samples collected in the community of Boa Fé (BF1, BF2, BF3, and BF4). In this group all the samples presented a high risk of salinization, since their $\mathrm{EC}_{\mathrm{w}}$ values $\left(6.20,6.40,6.20\right.$ and $\left.5.72 \mathrm{dS} \mathrm{m}^{-1}\right)$ (Table 4) restrict their use in irrigation, except in specific conditions of management (Terceiro Neto et al., 2013) like the mixture of water of different salinities, cultivation of salinity-tolerant plants (Dias, Ferreira, Liu, \& Suarez, 2016), or the use in hydroponic farming systems (Oliveira et al., 2017).

Also in relation to Group 2, the high values of SAR $\left(5.90,5.90,6.90\right.$, and $\left.9.96\left(\mathrm{mmolc} \mathrm{L}^{-1}\right)^{0.5}\right)$ present no risk of infiltration problems, since a high $\mathrm{EC}_{\mathrm{w}}$ can maintain clay partially flocculated. There would be a risk only when the EC is less than $1.9 \mathrm{dS} \mathrm{m}^{-1}$. However, the LSI and RSI values indicate that all samples of this group have tendency to cause incrustation. In addition, the concentrations of sodium and chloride confer a high degree of toxicity to these waters.

In Group 3, formed by samples JA4, JU4, JU1, PF3, LR4, PF4 and JU2, were observed $\mathrm{EC}_{\mathrm{w}}$ equal to 2.30, 1.95, $2.01,0.57,0.95,0.98$, and $2.30 \mathrm{dS} \mathrm{m}^{-1}$, respectively. Except for PF3, all samples were classified as moderate risk of salinization. The values of $6.25 ; 3.42 ; 1.80 ; 6.11 ; 9.15 ; 8.59$, and $2.20\left(\mathrm{mmolc} \mathrm{L}^{-1}\right)^{0.5}$ were observed for SAR, representing moderate restriction concerning the risk of sodification, except for JU1 and JU2 which showed no restriction. It should be emphasized that the waters of this group have $\mathrm{Ca}^{2+} / \mathrm{Mg}^{2+}$ ratios lower than the unit in PF3 and PF4. According to Antas and Morais (2011), waters with values of $\mathrm{Ca}^{2+} / \mathrm{Mg}^{2+}$ ratio lower than the unit often cause calcium deficiency to the crop, due to the low levels of this element in relation to magnesium in the soil sorption complex and the competition between these cations by the exchange sites.

Ayers and Westcott (1999) point out that the productivity of most crops is lower in soils with high magnesium contents, or when irrigation water contains high levels of this element, even when the infiltration is adequate. According to Maia and Rodrigues (2012) this is due to calcium deficiency induced by the excess of exchangeable magnesium in the soil. In this situation, the effects of sodium are slightly higher when it is present in the irrigation water, or in the soil solution, since, due to the lower attraction force presented by magnesium, there may be dispersion of the clays, generating problems of infiltration. Another characteristic inherent to the waters of this group is the low possibility of crust formation due to the low probability of precipitation of $\mathrm{CaCO}_{3}$. This fact reduces the incidence of emitter obstruction, since the LSI values are between 0.26 and 0.81 and those of the RSI are between 5.67 and 3.18.

Group 4 presented the least similarity among its components. Possibly, if a larger number of groups were determined, these samples would not be grouped. However, EM2 and PF2 exhibit proximity in EC values and $\mathrm{K}^{+}$ concentrations. The samples show moderate restriction due to the risk of salinization and no restriction due to soil sodification. However, both have a high risk of obstruction in relation to the LSI values, and especially the RSI. The concentrations of $\mathrm{Ca}^{2+}$ and $\mathrm{Mg}^{2+}$ also differ from the other samples from the same community, presenting values of 40.80 and 21.60 (PF2) versus 10.30 and 5.30 (PF1); 2.20 and 3.30 (PF3) and 2.40 and 4.30 mmol L ${ }^{-1}$ (PF4).

Group 5, formed by EM3 and EM4, and Group 2, formed only by samples from the Boa Fé community, are composed of samples from a single community grouped due to their high SAR. The waters of these groups present moderate restriction due to the risk of salinization (1.93 and $1.98 \mathrm{dS} \mathrm{m}^{-1}$, respectively) and infiltration problems $\left(16.90\right.$ and $\left.15.74\left(\text { mmolc L }^{-1}\right)^{0.5}\right)$, besides having low tendency of incrustation. However, their sodium concentrations exceed by more than ten times the threshold value of intoxication by this element. In addition, the $\mathrm{Ca}^{2+} / \mathrm{Mg}^{2+}$ ratio higher than the unit aggravates the problems of infiltration and can lead to calcium deficiency in crops.

Group 6 presented the greatest dissimilarity in relation to the others and presented the only water samples with corrosive characteristics denoted by LSI larger than the unit and RSI higher than 9. This is due to its low buffering power due to the low concentrations of bicarbonate and carbonate. In addition, the waters do not present restriction due to the risk of salinization or infiltration problems, however, due to the low $\mathrm{EC}_{\mathrm{w}}$ values, salt leaching may occur in the root zone. 


\subsection{Purified Water}

The grouping analysis of purified water resulted in the dendogram shown in Figure 2. The Jacu community at E3 (JA3) has the highest Euclidean distance coefficient, differing from all others, possibly because it is the only sample that does not present waters with corrosive tendencies (LSI $=0.26$ and RSI $=7.69$ ). The other samples presented negative values for the LSI (between -1.08 and -4.01) and high values for the RSI (between 9.18 and 13.54), a fact that increases their power of dissolution of salts (Table 5).

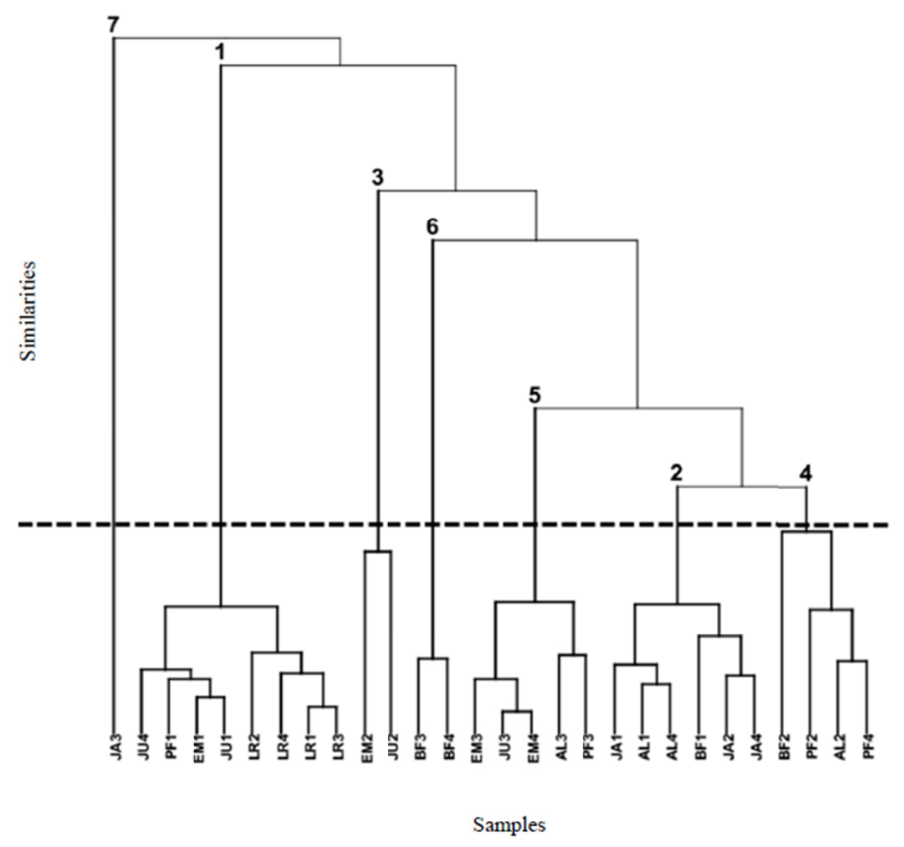

Figure 2. Dendrogram of the hierarchical clustering analysis for the 28 points of water purified by reverse osmosis at the desalinations plants in West Potiguar

Group 1 was formed by the samples with smaller sum of squares of $\mathrm{EC}_{\mathrm{w}}$, which do not present restriction due to the risk of salinization. However, when comparing the values of EC and SAR, it can be observed that they can cause problems of infiltration irrespective of the SAR value $\left(\mathrm{EC}_{\mathrm{w}}<0.2 \mathrm{dS} \mathrm{m}{ }^{-1}\right)$. The $\mathrm{Ca}^{2+} / \mathrm{Mg}^{2+}$ ratio is less than 1 in the LR2 and LR4 samples, which accentuates the effects of SAR. However, LSI values $\leq-1.86$ and, especially, RSI $\geq 11.37$ demonstrate the corrosive tendency of these waters (Table 5). Ayers and Westcot (1999) point out that, regardless of the SAR value, very low salinity waters $\left(\mathrm{EC}_{\mathrm{w}}<0.2 \mathrm{dS} \mathrm{m}^{-1}\right)$ invariably cause infiltration problems. 
Table 5. Results of the hierarchical clustering analysis by the Ward method for the 28 points of collection of purified water by reverse osmosis at desalinations plants in the rural settlements of the West Potiguar

\begin{tabular}{|c|c|c|c|c|c|c|c|c|c|c|c|c|}
\hline Group & Locality & $\mathrm{EC}_{\mathrm{w}}$ & $\mathrm{K}^{+}$ & $\mathrm{Na}^{+}$ & $\mathrm{Ca}^{2+}$ & $\mathrm{Mg}^{2+}$ & $\mathrm{Cl}^{-}$ & $\mathrm{CO}_{3}{ }^{2-}$ & $\mathrm{HCO}_{3}{ }^{-}$ & SAR & LSI & RSI \\
\hline & & $\mathrm{dS} \mathrm{m}^{-1}$ & -----. & - & ----- & $-\mathrm{mmo}$ & $\mathrm{L}^{-1}--$ & - & & & & \\
\hline \multirow[t]{7}{*}{ G1 } & $\mathrm{LR}_{1}$ & 0.01 & 0.00 & 0.19 & 0.05 & 0.03 & 0.60 & 0.00 & 0.10 & 0.90 & -3.34 & 13.54 \\
\hline & $\mathrm{EM}_{1}$ & 0.10 & 0.00 & 0.40 & 0.10 & 0.20 & 0.60 & 0.00 & 0.30 & 1.00 & -1.86 & 11.37 \\
\hline & $\mathrm{JU}_{1}$ & 0.14 & 0.02 & 0.32 & 0.10 & 0.10 & 0.80 & 0.00 & 0.30 & 1.00 & -2.55 & 12.08 \\
\hline & $\mathrm{PF}_{1}$ & 0.16 & 0.02 & 0.58 & 0.20 & 0.00 & 0.60 & 0.00 & 0.10 & 1.80 & -2.49 & 12.20 \\
\hline & $\mathrm{LR}_{2}$ & 0.08 & 0.39 & 0.15 & 0.05 & 0.15 & 0.20 & 0.00 & 0.40 & 0.50 & -2.68 & 12.36 \\
\hline & $\mathrm{LR}_{3}$ & 0.03 & 0.21 & 0.26 & 0.10 & 0.10 & 0.60 & 0.00 & 0.10 & 0.80 & -3.24 & 13.18 \\
\hline & $\mathrm{LR}_{4}$ & 0.03 & 0.00 & 0.18 & 0.10 & 0.20 & 0.80 & 0.00 & 0.40 & 0.46 & -4.01 & 13.35 \\
\hline \multirow[t]{6}{*}{$\mathrm{G} 2$} & $\mathrm{AL}_{1}$ & 0.17 & 0.02 & 0.67 & 0.30 & 0.40 & 0.80 & 0.00 & 0.70 & 1.10 & -1.17 & 9.87 \\
\hline & $\mathrm{BF}_{1}$ & 0.33 & 0.02 & 1.50 & 0.36 & 0.44 & 2.00 & 0.00 & 0.20 & 2.40 & -1.83 & 11.01 \\
\hline & $\mathrm{JA}_{1}$ & 0.29 & 0.02 & 0.70 & 0.22 & 0.48 & 1.00 & 0.00 & 0.30 & 1.20 & -1.78 & 11.00 \\
\hline & $\mathrm{JA}_{2}$ & 0.29 & 0.02 & 0.70 & 0.50 & 0.30 & 2.00 & 0.00 & 0.30 & 1.10 & -2.42 & 11.29 \\
\hline & $\mathrm{AL}_{4}$ & 0.15 & 0.03 & 0.83 & 0.40 & 0.20 & 1.60 & 0.00 & 0.70 & 1.52 & -1.76 & 10.33 \\
\hline & $\mathrm{JA}_{4}$ & 0.18 & 0.03 & 0.90 & 0.90 & 0.30 & 2.60 & 0.00 & 0.50 & 1.17 & -2.46 & 10.83 \\
\hline \multirow[t]{2}{*}{ G3 } & $\mathrm{EM}_{2}$ & 1.60 & 2.03 & 0.40 & 0.30 & 0.10 & 0.60 & 0.00 & 0.90 & 0.90 & -2.24 & 10.92 \\
\hline & $\mathrm{JU}_{2}$ & 1.70 & 0.39 & 0.23 & 0.20 & 0.20 & 0.80 & 0.00 & 1.00 & 0.50 & -2.09 & 10.91 \\
\hline \multirow[t]{4}{*}{ G4 } & $\mathrm{AL}_{2}$ & 0.10 & 0.39 & 0.66 & 0.60 & 0.20 & 0.80 & 0.00 & 0.90 & 1.00 & -1.11 & 9.37 \\
\hline & $\mathrm{BF}_{2}$ & 0.40 & 0.95 & 2.02 & 0.70 & 0.20 & 2.20 & 0.00 & 1.00 & 3.00 & -1.21 & 9.42 \\
\hline & $\mathrm{PF}_{2}$ & 0.31 & 0.44 & 0.66 & 1.40 & 0.60 & 2.00 & 0.00 & 0.60 & 0.70 & -1.10 & 9.23 \\
\hline & $\mathrm{PF}_{4}$ & 0.17 & 0.05 & 0.08 & 0.90 & 0.10 & 1.20 & 0.00 & 0.90 & 0.12 & -1.08 & 9.18 \\
\hline \multirow[t]{6}{*}{ G5 } & $\mathrm{EM}_{3}$ & 0.07 & 0.03 & 0.35 & 0.30 & 1.40 & 1.20 & 0.00 & 0.30 & 0.38 & -1.72 & 10.75 \\
\hline & $\mathrm{AL}_{3}$ & 0.11 & 0.03 & 0.67 & 0.50 & 1.70 & 1.00 & 0.00 & 0.60 & 0.64 & -1.32 & 9.84 \\
\hline & $\mathrm{PF}_{3}$ & 0.11 & 0.05 & 0.08 & 0.80 & 1.20 & 0.80 & 0.00 & 0.90 & 0.08 & -1.14 & 9.28 \\
\hline & $\mathrm{JU}_{3}$ & 0.07 & 0.02 & 0.53 & 0.30 & 0.90 & 1.20 & 0.00 & 0.40 & 0.69 & -2.10 & 11.00 \\
\hline & $\mathrm{PF}_{3}$ & 0.11 & 0.05 & 0.08 & 0.80 & 1.20 & 0.80 & 0.00 & 0.90 & 0.08 & -1.14 & 9.28 \\
\hline & $\mathrm{EM}_{4}$ & 0.08 & 0.02 & 0.48 & 0.30 & 1.00 & 1.40 & 0.00 & 0.50 & 0.60 & -1.84 & 10.64 \\
\hline \multirow[t]{2}{*}{ G6 } & $\mathrm{BF}_{3}$ & 0.30 & 0.04 & 2.84 & 0.40 & 0.50 & 4.20 & 0.00 & 0.20 & 4.23 & -2.14 & 11.27 \\
\hline & $\mathrm{BF}_{4}$ & 0.30 & 0.03 & 2.08 & 0.20 & 0.30 & 3.20 & 0.00 & 0.30 & 4.16 & -2.73 & 11.99 \\
\hline G7 & $\mathrm{JA}_{3}$ & 0.14 & 0.10 & 0.11 & 0.90 & 0.10 & 1.60 & 0.40 & 0.50 & 0.15 & 0.26 & 7.69 \\
\hline
\end{tabular}

Note. $\mathrm{EC}_{\mathrm{w}}=$ electrical conductivity of water; $\mathrm{SAR}=$ sodium absorption ratio; $\mathrm{LSI}=$ Langelier saturation index; $\mathrm{RSI}=$ Ryznar stability index. The initials of the localities $(\mathrm{JA}=\mathrm{Jacu}, \mathrm{LR}=$ Lagoa Rasa, $\mathrm{EM}=\mathrm{Ema}, \mathrm{AL}=$ Alagoinha, $\mathrm{JU}=$ Juazeiro, $\mathrm{BF}=$ Boa Fé, $\mathrm{PF}=\mathrm{Pau}$ dos Ferros) are accompanied by the numbers 1, 2, 3, and 4, corresponding respectively to collection periods: E1; E2; E3, and E4.

Samples from Group 2 were grouped according to the lower $\mathrm{K}^{+}$variability and also did not present any restriction on the possibility of soil salinization. However, even with $\mathrm{EC}_{\mathrm{w}}$ values higher than those of Group 1 (between 0.15 and $0.33 \mathrm{dS} \mathrm{m}^{-1}$ ), when the SAR was considered these waters classify as having increased and / or severe risk of infiltration problems, especially AL1, BF1 and JA1. Their values of $\mathrm{Ca}^{2+} / \mathrm{Mg}^{2+}$ were, respectively, $0.75,0.82$ and 0.46 , and JA1 presented $\mathrm{Ca}^{2+} / \Sigma$ Cations values equal to 0.15 , boundary value below which there is a nutritional deficit of $\mathrm{Ca}^{2+}$.

Samples EM2 and JU2 which form Group $3\left(\mathrm{EC}_{\mathrm{w}}\right.$ equal to 1.60 and $1.70 \mathrm{dS} \mathrm{m}^{-1}$, respectively), present moderate risk of salinization of the soil and no risk of sodification, however, it is necessary to emphasize the low ratio $\mathrm{Ca}^{2+} / \Sigma$ Cations (0.11), below the threshold of 0.15 for EM2, which can induce calcium deficiency to crops.

All samples from Group 5 have $\mathrm{EC}_{\mathrm{w}}$ values lower than $0.2 \mathrm{dS} \mathrm{m}^{-1}$ and a calcium concentration lower than that of $\mathrm{Mg}^{2+}$, which indicates their high tendency to cause infiltration problems. Although the samples from Group 6 had the same $\mathrm{EC}_{\mathrm{w}}$ values for the two communities $\left(0.3 \mathrm{dS} \mathrm{m}^{-1}\right)$, they also presented a severe risk of sodification (RAS above $\left.4.0\left(\text { mmolc }{ }^{-1}\right)^{0.5}\right)$. In addition, their $\mathrm{Ca}^{2+} / \mathrm{Mg}^{2+}$ and $\mathrm{Ca}^{2+} / \Sigma$ Cations ratios were lower than the boundary values.

\subsection{Reject Brine from Reverse Osmosis}

The clustering analysis for the reject water resulted in the dendogram of Figure 3, composed of seven groups. 


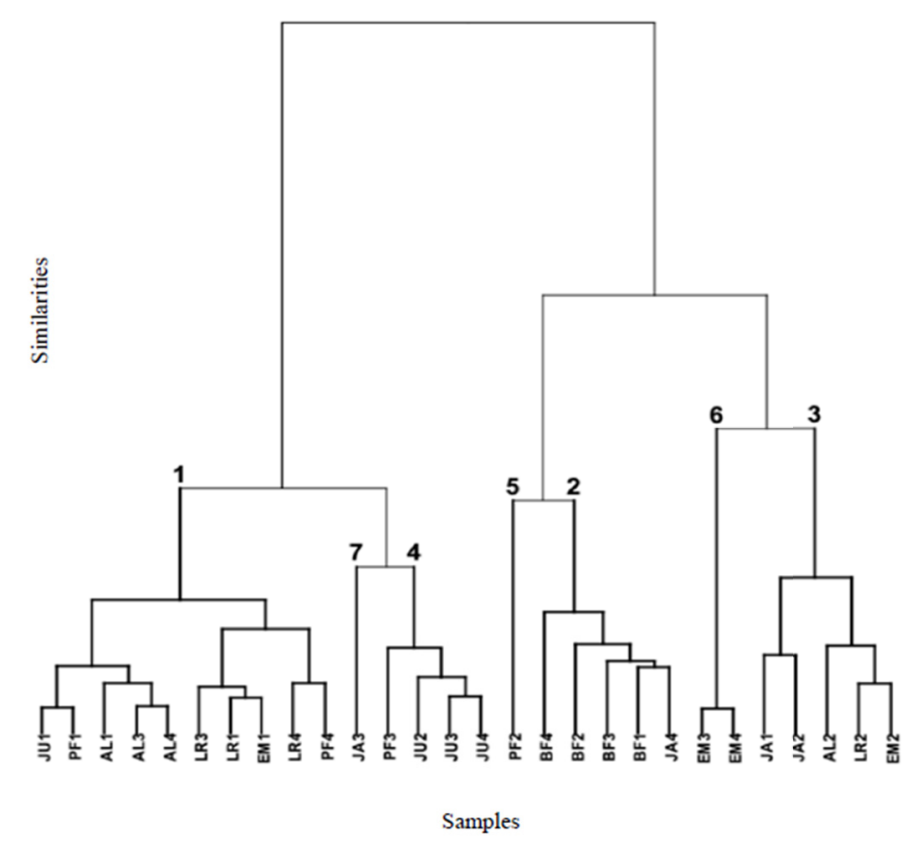

Figure 3. Dendrogram of the hierarchical clustering analysis for the 28 points of reject brine from reverse osmosis desalination plant in West Potiguar

Two samples were found with high dissimilarity in relation to the others: PF2 that presented the highest value of $\mathrm{EC}_{\mathrm{w}}$ among all the samples, and JA3 that was the only sample with negative LSI, indicating a slight corrosive tendency of its water, possibly due to its $\mathrm{EC}_{\mathrm{w}}$ of $0.22 \mathrm{dS} \mathrm{m}^{-1}$ (Table 6).

In general, the reject waters obtained a classification similar to the brackish water from wells, a fact that is indicated by the similarity between the components of each group in the two classes. The samples from Group 1 were listed according to the lowest variance of LSI and RSI. The electrical conductivity of these waters varies between 1.15 and $2.98 \mathrm{dS} \mathrm{m}^{-1}$, classifying them as of increasing risk of salinization according to Ayers and Westcott (1999). 
Table 6. Results of the hierarchical clustering analysis by the Ward method for the 28 points of collection of reject brine from osmosis reverses desalination plants in the rural settlements of the West Potiguar

\begin{tabular}{|c|c|c|c|c|c|c|c|c|c|c|c|c|}
\hline Group & Locality & $\mathrm{EC}_{\mathrm{w}}$ & $\mathrm{K}^{+}$ & $\mathrm{Na}^{+}$ & $\mathrm{Ca}^{2+}$ & $\mathrm{Mg}^{2+}$ & $\mathrm{Cl}^{-}$ & $\mathrm{CO}_{3}{ }^{2-}$ & $\mathrm{HCO}_{3}^{-}$ & SAR & LSI & RSI \\
\hline & & $\mathrm{dS} \mathrm{m}^{-1}$ & $-\overline{---}$ & 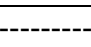 & - & - mmol & $L^{-1}-\cdots$ & & 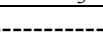 & & & \\
\hline \multirow[t]{10}{*}{ G1 } & LR1 & 1.48 & 0.01 & 10.24 & 4.10 & 1.80 & 5.00 & 1.80 & 7.10 & 6.00 & 1.16 & 5.31 \\
\hline & EM1 & 2.98 & 0.29 & 15.85 & 5.80 & 5.60 & 20.40 & 1.20 & 9.10 & 6.60 & 1.08 & 5.23 \\
\hline & AL1 & 1.54 & 0.17 & 4.51 & 10.07 & 0.93 & 8.80 & 0.80 & 6.50 & 1.90 & 1.18 & 5.02 \\
\hline & JU1 & 2.97 & 0.58 & 6.96 & 16.80 & 5.10 & 27.00 & 0.60 & 2.00 & 2.10 & 0.87 & 5.54 \\
\hline & PF1 & 2.24 & 0.29 & 8.49 & 9.00 & 6.14 & 11.60 & 0.60 & 2.50 & 3.10 & 0.82 & 5.78 \\
\hline & LR3 & 1.15 & 1.39 & 8.93 & 4.10 & 1.80 & 6.20 & 1.70 & 7.00 & 5.20 & 1.23 & 5.24 \\
\hline & AL3 & 1.50 & 0.56 & 12.99 & 6.20 & 8.00 & 9.40 & 0.20 & 6.00 & 4.88 & 1.09 & 5.42 \\
\hline & LR4 & 1.31 & 0.04 & 19.25 & 3.70 & 2.50 & 6.00 & 0.20 & 10.80 & 10.93 & 1.11 & 5.37 \\
\hline & AL4 & 1.51 & 0.35 & 10.27 & 8.70 & 6.60 & 9.60 & 0.00 & 9.80 & 3.71 & 1.08 & 5.10 \\
\hline & PF4 & 1.74 & 1.15 & 26.36 & 3.70 & 7.40 & 8.20 & 0.60 & 6.50 & 11.19 & 0.87 & 5.80 \\
\hline \multirow[t]{5}{*}{$\mathrm{G} 2$} & $\mathrm{BF} 1$ & 8.41 & 0.37 & 29.33 & 29.72 & 24.58 & 92.00 & 0.80 & 2.40 & 6.50 & 1.37 & 4.75 \\
\hline & BF2 & 9.30 & 2.49 & 38.90 & 44.00 & 15.70 & 100.00 & 0.20 & 6.00 & 7.10 & 1.27 & 4.48 \\
\hline & BF3 & 7.30 & 1.34 & 40.09 & 36.80 & 26.70 & 87.00 & 0.00 & 1.40 & 7.12 & 0.72 & 5.75 \\
\hline & BF4 & 7.56 & 1.13 & 72.63 & 47.00 & 25.00 & 82.00 & 0.20 & 7.00 & 12.11 & 1.70 & 3.95 \\
\hline & JA4 & 4.24 & 1.13 & 30.93 & 20.50 & 19.00 & 61.00 & 0.10 & 5.50 & 6.96 & 1.21 & 4.88 \\
\hline \multirow[t]{5}{*}{ G3 } & JA1 & 6.23 & 0.88 & 29.33 & 24.90 & 3.20 & 60.60 & 2.00 & 7.00 & 7.80 & 2.07 & 3.67 \\
\hline & LR2 & 1.80 & 2.13 & 13.01 & 4.30 & 2.80 & 7.40 & 3.00 & 15.00 & 6.90 & 1.84 & 4.33 \\
\hline & EM2 & 3.48 & 2.44 & 19.14 & 7.00 & 6.20 & 18.20 & 2.00 & 19.00 & 7.40 & 1.60 & 4.34 \\
\hline & AL2 & 2.00 & 3.67 & 3.64 & 11.80 & 2.30 & 10.20 & 2.20 & 10.40 & 1.40 & 1.88 & 4.00 \\
\hline & JA2 & 6.30 & 3.00 & 29.87 & 25.30 & 3.20 & 56.00 & 0.80 & 8.40 & 7.90 & 1.61 & 4.17 \\
\hline \multirow[t]{4}{*}{ G4 } & JU2 & 3.20 & 2.69 & 9.09 & 18.00 & 5.50 & 27.60 & 0.00 & 3.00 & 2.70 & 0.65 & 5.76 \\
\hline & JU3 & 1.95 & 1.26 & 15.20 & 10.40 & 6.10 & 19.40 & 0.00 & 1.40 & 5.30 & 0.54 & 6.42 \\
\hline & PF3 & 0.71 & 0.51 & 15.99 & 2.80 & 5.40 & 6.80 & 0.40 & 0.50 & 7.90 & 0.38 & 7.14 \\
\hline & JU4 & 2.70 & 1.31 & 15.89 & 1900 & 11.50 & 37.00 & 0.00 & 2.50 & 4.07 & 0.57 & 5.89 \\
\hline G5 & PF2 & 13.05 & 3.67 & 51.33 & 49.00 & 26.50 & 112.00 & 0.00 & 28.50 & 8.40 & 1.60 & 3.47 \\
\hline \multirow[t]{2}{*}{ G6 } & EM3 & 2.40 & 0.99 & 48.30 & 10.00 & 2.40 & 14.80 & 0.00 & 12.10 & 19.40 & 1.15 & 4.90 \\
\hline & EM4 & 2.51 & 1.04 & 46.36 & 9.30 & 2.70 & 16.40 & 0.20 & 13.80 & 18.93 & 1.47 & 4.54 \\
\hline G7 & JA3 & 0.22 & 0.13 & 1.97 & 1.70 & 1.50 & 3.40 & 0.00 & 0.40 & 1.56 & -0.69 & 8.89 \\
\hline
\end{tabular}

Note. $\mathrm{EC}_{\mathrm{w}}=$ electrical conductivity of water; $\mathrm{SAR}=$ sodium absorption ratio; LSI = Langelier saturation index; RSI $=$ Ryznar stability index. The initials of the localities $(\mathrm{JA}=\mathrm{Jacu}, \mathrm{LR}=$ Lagoa Rasa, EM $=\mathrm{Ema}, \mathrm{AL}=$ Alagoinha, $\mathrm{JU}=$ Juazeiro, BF $=$ Boa Fé, PF $=$ Pau dos Ferros) are accompanied by the numbers 1, 2, 3, and 4, corresponding respectively to collection periods: E1; E2; E3, and E4.

In Lagoa Rasa and Pau dos Ferros in E4 (LR4 and PF4), with respect to $\mathrm{EC}_{\mathrm{w}}$ and SAR, the classifications in no-risk or moderate risk of sodicity were observed, even with high values $\left(10.93\right.$ and $\left.11.19\left(\mathrm{mmolc} \mathrm{L}^{-1}\right)^{0.5}\right)$. This is due to the high EC values, since the presence of high calcium concentrations minimizes the dispersing effects of sodium.

However, PF4 deserves more caution regarding its use, since it does not have enough calcium to neutralize the dispersive effects $\left(\mathrm{Ca}^{2+} / \mathrm{Mg}^{2+}=0.50\right)$, with $\mathrm{Na}^{+}$being the cation that contributes most to its EC. Regarding to toxicity, all the samples presented concentrations of sodium, chloride and bicarbonate that classifies them as having a strong to severe risk. Regarding the formation of incrustations, these waters have a slightly fouling tendency due to its LSI $>1$ and RSI $<6$.

Group 2, similar to Group 1, was formed due to the lower variability of the sum of squares of $\mathrm{HCO}_{3}{ }^{-}$. The waters of this group present severe restriction regarding salinization due to their high $\mathrm{EC}_{\mathrm{w}}$, whose values make practically impracticable the use of these water for irrigation. In similar works, Oliveira et al. (2017) and Anders et al. (2017) found that between the wells analyzed, respectively 93.60 and $90 \%$ of the wastewater samples from desalinators presented increasing or severe risk of soil salinization. The authors state that these waters are not suitable for irrigation under normal conditions and may be used on soils with good drainage, provided that adequate leaching depth is applied and salt tolerant crops are used. According to Almeida Neto and Matos (2009), waters of this type cannot be used in soils that have poor drainage and even in soils with good drainage, it may be necessary to adopt special practices to control salinity, besides the use of species that are very tolerant to salts. 
Group 3 also presents samples with moderate to severe risk of salinization, high risk of sodium and chloride toxicity, and moderate risk of emitter obstruction. Two of the five samples from this group belong to the community of Jacu, and the other samples belong to the communities of Ema, Alagoinha and Lagoa Rasa.

Group 4 has samples from the Juazeiro community in three of the four sampling periods, as well as Pau dos Ferros in the third sampling. The latter is worth mentioning because of the low danger of salinization and high risk of problems with infiltration due to its low $\mathrm{EC}_{\mathrm{w}}$ and high SAR. In addition, this is the only sample with LSI and RSI balanced, that is, without corrosive or fouling tendencies, while the other components of the group have slight fouling tendency.

The locality of Pau dos Ferros, in the second sampling, and Jacu, in the third sample, present a high dissimilarity of the other samples and, therefore, are the only samples of their groups (5 and 7, respectively), the first one because of its high and the second by their low concentrations of salt. It should be emphasized that, while all other samples of wastewater presented fouling trends, JA3 has corrosive tendencies, so it does not appear in any of the groups, being classified separately.

Group 6 had the lowest Euclidean distance between its components, possibly because they belonged to the same community and were collected during the rainy season.

\section{Conclusions}

The brackish water of the studied region presented moderate to severe restriction with respect to the salinity and toxicity of sodium and chloride.

Purified water showed moderate to severe restriction with respect to sodicity.

The reject brine from osmosis reverse desalination plants had severe restrictions to use of irrigation crop due risk of salinization, sodium and chloride toxicity.

\section{References}

Almeida Neto, O. B., \& Matos, A. T. (2009). Influência da qualidade da água e irrigação na dispersão da argila de Latossolos. Revista Brasileira de Ciência do Solo, 33(6), 1571-1581. https://doi.org/10.1590/ S0100-06832009000600006

APHA (American Public Health Association). (2005). Standard methods for the examination of water and wastewater (22nd ed.). Wasghington: American Public Health Association.

Anders, C. R., Melo, M. R. S., Dias, N. S., Souza, A. C. M., Portela, J. C., \& Sousa Junior, F. S. (2017). Caracterização das águas de estações de tratamento na mesorregião do oeste potiguar, Brasil. Revista Brasileira de Agricultura Irrigada, 11(3), 1430-1437. https://doi.org/10.7127/rbai.v11n300568

Antas, F. P. S., \& Morais, E. R. C. (2011). Monitoramento da qualidade química da água para fins de irrigação no Rio Açú, RN. Holos, 4, 23-28. https://doi.org/10.15628/holos.2011.629

Ayers, R. S., \& Westcot, D. W. (1999). A qualidade da água na agricultura (2nd ed.). Campina Grande: UFPB.

Barroso, A. A. F., Gomes, G. E., Lima, A. E. O., Palacio, H. A. Q., \& Lima, C. A. (2011). Avaliação da qualidade da agua para irrigação na região Centro Sul no Estado do Ceara. Revista Brasileira de Engenharia Agrícola e Ambiental, 15(6), 588-593. https://doi.org/10.1590/S1415-43662011000600008

Bush, J. A., Vanneste, J., \& Cath, T. Y. (2016). Membrane distillation for concentration of hypersaline brines from the Great Salt Lake: Effects of scaling and fouling on performance, efficiency, and salt rejection. Separation and Purification Technology, Amsterdã, 170, 78-91. https://doi.org/10.1016/j.seppur.2016. 06.028

Cirilo, J. A. (2008). Políticas públicas de recursos hídricos para o semi-árido. Estudos Avançados, 22(63), 61-82. https://doi.org/10.1590/S0103-40142008000200005

Dias, N. S., Ferreira, J. F. S., Liu, X., \& Suarez, D. S. (2016). Jerusalem artichoke (Helianthus tuberosus L.) maintains high inulin, tuber yield, and antioxidant capacity under moderately-saline irrigation waters. Industrial Crops and Products, 94, 1009-1024. https://doi.org/10.1016/j.indcrop.2016.09.029

Grades, E. A. (2004). Modelling and simulation of $\mathrm{CO}_{2}$ release in multiple-effect distillers for seawater desalination. Martin Luther Universität Halle-Wittenberg, Halle, German.

Lima, A. O., Lima-Filho, F. P., Dias, N. S., Rego, P. R. A., \& Ferreira Neto, M. (2017). Mechanisms controlling surface water quality in the Cobras river sub-basin, northeastern Brazil. Revista Caatinga, 30(1), 181-189. https://doi.org/10.1590/1983-21252017v30n120rc 
Maia, C. E., \& Rodrigues, K. K. R. (2012). Proposal for an index to classify irrigation water quality: A case study in northeastern Brazil. Revista Brasileira de Ciência do Solo, 36(3), 823-830. https://doi.org/ $10.1590 / \mathrm{S} 0100-06832012000300013$

Mantovani, E. C; Bernardo, S., \& Palaretti, L. F. (2007). Irrigação: Princípios e métodos (1st ed.). Viçosa: UFV.

Oliveira, A. M., Dias, N. S., Freitas, J. J. R., Martins, D. R. M., \& Rabelo, L. N. (2017). Avaliação físico-química das águas do processo de dessalinização de poços salobros e salinos em comunidades rurais do oeste potiguar. Águas Subterrâneas, 31(2), 58-73. https://doi.org/10.14295/ras.v31i2.28663

Sharma, S. (1996). Applied multivariate techniques (1st ed.). New York: John Wiley \& Sons.

Soares, T. M., Silva, I. J. O., Duarte, S. N., \& Silva, E. F. F. E. (2006). Destinação de águas residuárias provenientes do processo de dessalinização por osmose reversa. Revista Brasileira de Engenharia Agrícola e Ambiental, 10(3), 730-737. https://doi.org/10.1590/S1415-43662006000300028

Terceiro Neto, C, C. P., Gheyi, H. R., Medeiros, J. F., Dias, N. S., \& Campos, M. S. (2013). Produtividade e qualidade de melão sob manejo com água de salinidade crescente. Pesquisa Agropecuária Tropical, 43(4), 354-362. https://doi.org/10.1590/S1983-40632013000400007

Ward, J. H. (2012). Hierarquical grouping to optimize an objective function. Journal of the American Statistical Association, 58(301), 236-244. https://doi.org/10.1080/01621459.1963.10500845

\section{Copyrights}

Copyright for this article is retained by the author(s), with first publication rights granted to the journal.

This is an open-access article distributed under the terms and conditions of the Creative Commons Attribution license (http://creativecommons.org/licenses/by/4.0/). 